Review

\title{
Green Infrastructures and the Consideration of Their Soil-Related Ecosystem Services in Urban Areas-A Systematic Literature Review
}

\author{
Pia Minixhofer* ${ }^{(D)}$ and Rosemarie Stang1*(D) \\ Department of Civil Engineering and Natural Hazards, Institute of Soil Bioengineering and Landscape \\ Construction, University of Natural Resources and Life Sciences, A-1190 Vienna, Austria \\ * Correspondence: pia.minixhofer@boku.ac.at (P.M.); rosemarie.stangl@boku.ac.at (R.S.)
}

Citation: Minixhofer, P.; Stangl, R. Green Infrastructures and the

Consideration of Their Soil-Related Ecosystem Services in Urban Areas-A Systematic Literature Review. Sustainability 2021, 13, 3322. https://doi.org/10.3390/ su13063322

Academic Editor: Brian Deal

Received: 15 February 2021

Accepted: 12 March 2021

Published: 17 March 2021

Publisher's Note: MDPI stays neutral with regard to jurisdictional claims in published maps and institutional affiliations.

Copyright: (c) 2021 by the authors. Licensee MDPI, Basel, Switzerland. This article is an open access article distributed under the terms and conditions of the Creative Commons Attribution (CC BY) license (https:// creativecommons.org/licenses/by/ $4.0 /)$.

\begin{abstract}
Although urban soils are strongly influenced by human activities, they provide a wide range of Ecosystem Services (ES) as long as they are not sealed off. This is a major sustainability issue as the loss of soil functions directly impacts ES and further on the possibility to adapt to the effects of the climate crisis. Green Infrastructure (GI) measures can be utilized to restore previously covered soil surfaces and compensate for lost soil functions. We conducted a systematic literature review to investigate the extent of peer-reviewed publications on GI measures in (peri-) urban areas covering soil-related ES. After identifying the relevant publications $(n=284)$, we generated an overview of the annual, spatial, and thematic distribution of the publications. Then, we employed an extended content analysis of the published focus topics to assess the representation of soil-related ES provided by GI. The content analysis revealed that the representation of soil-related ES in GI measures focused heavily on the contribution of soil to stormwater management. Detailed assessment of the interconnection of GI measures with key soil-related ES were missing. So far, the assessment of the loss of soil-related ES is not covered extensively in GI research publications.
\end{abstract}

Keywords: green infrastructure; soil functions; ecosystem services; systematic literature review; soil function loss

\section{Introduction}

The pressure on soil and land in (peri-) urban areas increases due to competing land uses such as living, working, infrastructure, energy, or recreation, as a result from intensifying urban immigration and the amplifying effects from the climate crisis [1]. Although urban soils are strongly influenced by human activities and highly heterogenous in their chemical, physical, and biological properties, they can still provide a wide range of provisioning, regulating and cultural Ecosystem Services (ES) [2,3] similarly to more natural soils [4-6] as long as they are not sealed off. Soil sealing describes various types of impervious land covering such as asphalt, concrete, buildings, or impermeable paving [5-7].

When the soil surface is sealed for land use purposes, as e.g., infrastructure or building development, valuable fundamental soil functions get lost [5]. According to the European Commission [8], these soil functions can be categorized into seven main topics: (1) biomass and food production; (2) nutrient and water storage, filtration and transformation; (3) biodiversity pool and habitats; (4) source of raw materials; (5) carbon pool; (6) physical and cultural environment for human activity as well as (7) archive of geological and archaeological heritage. The occurrence of these soil functions leads to raising soil quality within landuse boundaries. For this article, soil quality is defined as the multi-functionality of soil to sustain its environmental capacities, hence to provide soil-related ES. Soil quality promotes plant growth and biological productivity, secures biodiversity and habitation, supports animal and human health, regulates water infiltration, and buffers pollutants $[9,10]$.

However, in urban and landscape planning, soil is often perceived solely as a twodimensional parameter, because it is reduced to its area function. It is seen as a land surface 
without any depth. Soil quality and related functions linked with the third dimension, the soil depth, are usually disrespected $[3,4]$. This is a major sustainability issue, as the loss of soil functions directly impacts ES and further on the possibility to adapt to climate change. The reduction of intact soil systems, which occur predominantly in combination with (natural) green spaces, impacts the soil's ecological functions such as carbon storage [11-14], water retention [15-18], regulation of the micro- and mesoclimate $[7,19,20]$ or plant growth $[5,21,22]$. The loss of the green spaces will enhance the problems arising from increased Urban Heat Islands (UHI), from reduced stormwater retention areas, or from impaired air quality, which all lead to reduced quality of life $[3,5,23]$. Although urban soil quality and its preservation urgently need to be integrated into urban planning efforts, it is still not yet addressed widely [4,24].

The exploding land consumption in (peri-) urban areas entails an urgent need to promote sustainable land renaturation [25], especially since in urban areas potentially contaminated soils and very natural soils can exist in close proximity to each other [26]. In the EU, the promotion of Green Infrastructures (GI), defined as strategically planned (semi-) natural ecosystems to bring vegetation and (engineered) soils back to built environments [3,6,27], is a long-term strategy to combat the net soil loss and to ensure the delivery of ES in these areas [28]. GI measures can be utilized to restore previously covered soil surfaces, compensate for lost soil functions, and install newly designed features to generate green, permeable areas. Urban soils are always anthropogenically influenced and still capable of fulfilling a broad variety of the already mentioned soil functions and ES if not sealed [24]. Soils used for GI measures are also not undisturbed soil resources but altered and adapted for their particular purpose, oftentimes as part of a technical substrate. In 2006, an additional soil class, Technosols, was added to the World Reference Base of the International Union of Soil Sciences to describe the occurrence of the added anthropogenic materials or even impermeable surfaces [29].

So far, no systematic literature review covers soil functions and their loss in the context of GI. The aim of this systematic literature review is to demonstrate the extent of publications covering soil functions in peer-reviewed journals when investigating GI in urban or peri-urban areas, to identify the geographical scope, focus topics, and thematic distribution of the publications. Furthermore, we provide an analysis of the contextual discussion within the published focus topics, pointing out the soil-related ES provided by GI measures. The following research questions are addressed in this review study:

- How are soil-related Ecosystem Services represented within the peer-reviewed publications on Green Infrastructure?

- How are Green Infrastructures investigated in peer-reviewed publications in regard to soil-related Ecosystem Services and soil function loss?

\section{Materials and Methods}

\subsection{Systematic Literature Review}

This study was built on a systematic literature review [30,31] (Phase I, see Figure 1) to identify relevant scientific publications that were then subjected to a content analysis (Phase II). The four phases applied in this systematic literature review were identification (I.a), screening (I.b), eligibility (I.c), and inclusion (I.d) [30-33]. The pre-defined inclusion and exclusion criteria (given in Table 1), as well as the explicit methodology of the selection process allowed for a clear and transparent inclusion process whilst minimizing the bias.

To identify relevant publications, we searched the databases Web of Science and Scopus according to a pre-defined search string. The keyword "Green Infrastructure" was combined with the Boolean "AND" and "OR" with the keywords "soil", "city", and "urban" to find research articles within the broad scope of the research questions ("Green Infrastructure AND soil", "Green Infrastructure AND city", "Green Infrastructure AND urban", "Green Infrastructure AND soil AND city", "Green Infrastructure AND soil AND urban", "Green Infrastructure AND soil AND city OR urban"). The search terms were 
broad to assure the inclusion of publications even if they did not specifically address the topic of soil (functions) or soil quality with these specific words.

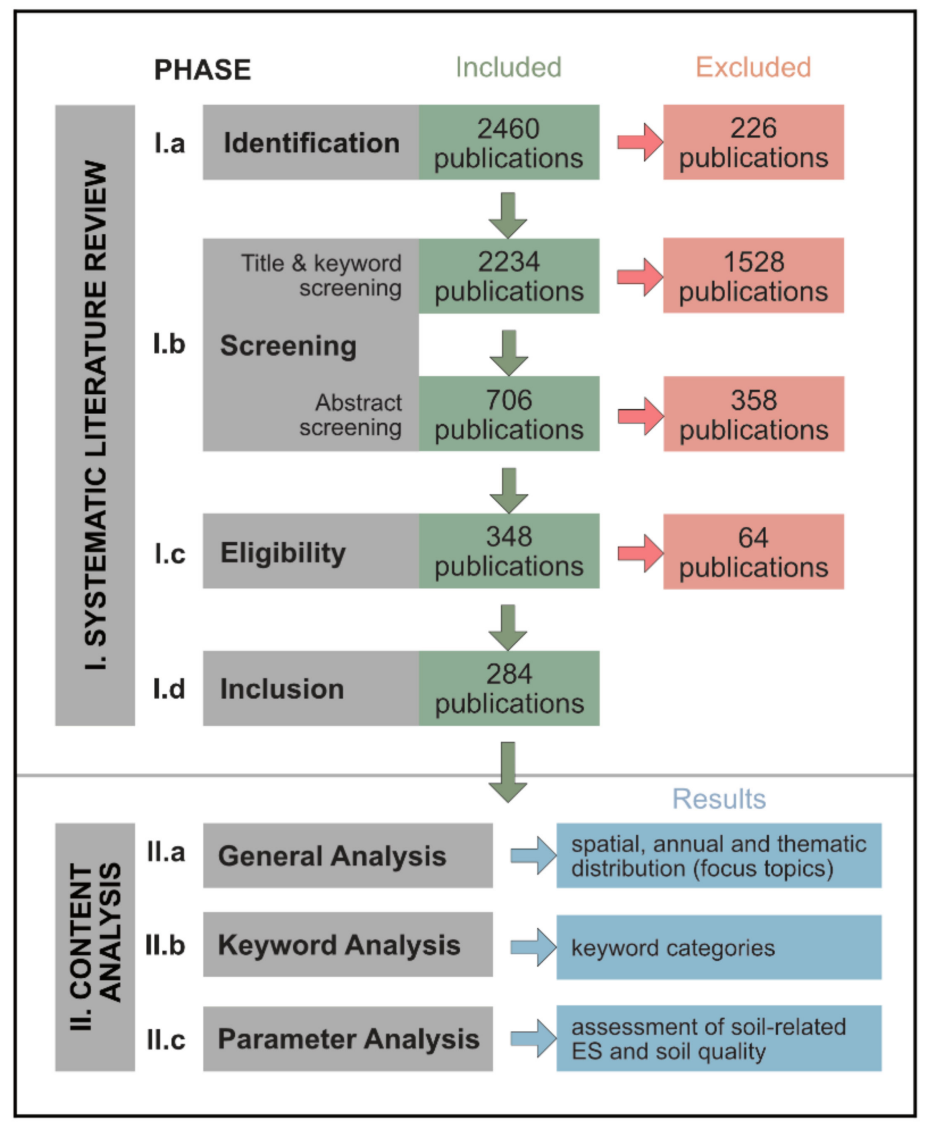

Figure 1. Process and flow diagram of the four phases of the systematic literature review (identification (I.a), screening (I.b), eligibility (I.c), and inclusion (I.d) and the extended content analysis (II.a-II.c).

Table 1. Specific inclusion and exclusion criteria for the phases I.a-I.c of the systematic literature review.

\begin{tabular}{|c|c|c|c|}
\hline Phase & Inclusion Criteria & Exclusion Criteria & Total $n^{\circ}$ of Excluded Articles \\
\hline Ia. Identification & $\begin{array}{l}\text { Keywords: Green } \\
\text { Infrastructure, soil, city, urban }\end{array}$ & Duplicates & 226 \\
\hline $\begin{array}{l}\text { Ib. Screening: } \\
\text { Title and keyword screening }\end{array}$ & & $\begin{array}{l}\text { No title; no abstract; } \\
\text { unrelated topic or measures } \\
\text { with no relevance to soil; } \\
\text { missing data; book chapters; } \\
\text { conference papers; editorials }\end{array}$ & 1528 \\
\hline $\begin{array}{l}\text { Ib. Screening: } \\
\text { Abstract screening }\end{array}$ & $\begin{array}{l}\text { Thematic relevance: } \\
\text { soil, permeability, infiltration, } \\
\text { ES and synonyms }\end{array}$ & $\begin{array}{c}\text { Abstract out of scope; } \\
\text { no access, not found; } \\
\text { no keywords; language (not } \\
\text { English or German) }\end{array}$ & 358 \\
\hline Ic. Eligibility & $\begin{array}{c}\text { Thematic relevance: } \\
\text { soil, permeability, infiltration, } \\
\text { ES and synonyms }\end{array}$ & Content out of scope & 64 \\
\hline
\end{tabular}

The original search resulted in 2460 publications (cut-off date 21 August 2019). After the removal of duplicates, the result was a total of 2234 original publications (see Figure 1, Phase I.a). The screening phase was conducted in two steps: 
First, the titles of the articles were scanned for thematic relevance (Phase I.b). All publications were initially included as long as they did not fulfill one of the exclusion criteria (see Table 1 for the total list of inclusion and exclusion criteria). We included publications throughout the identification and screening phase (Phases I.a and I.b) if they addressed soil or mentioned it as a factor. Exclusion criteria in Phase I.b applied when the publications were outside the scope of GI measures in any context of soil in urban areas (e.g., agriculture in rural areas, energy production, building performance, green walls with artificial substrates), showed missing data (e.g., no title, no abstract), or were not a research or review paper (e.g., book chapter, Conference Papers).

Second, the abstract screening for the remaining 706 publications identified 348 publications that were eligible for the qualitative content analysis. Further exclusion criteria for the abstract screening were e.g., no keywords or out of scope (see Table 1).

In the eligibility phase (I.c), only publications that addressed one soil-related ES or one of the soil functions directly or indirectly were included in the keyword and parameter analysis. We screened the contents of the selected 348 publications for the keywords "soil", "permeability", "infiltration", and synonyms to assess the thematic relevance of the publications. This process revealed 64 publications, which were out of scope due to their lack of addressing any soil issues in a deeper context.

\subsection{Extended Content Analysis}

The content analysis included the remaining 284 publications and employed a general analysis extended by an additional keyword and parameter analysis.

The general analysis (Phase II.a) of the publications provided an overview of the annual (see Figure 2, number of included publications by year) and spatial (see Figure A1 and Table A1, author's country affiliations) distribution [32]. Reoccurring and predominant topics were clustered to reveal focus topics of the thematic distributions within the publications (see Figure 3).

In the keyword analysis (Phase II.b, [32,34]), all keywords used in the publications were harmonized according to topic and then classified to one of the keyword categories. The categorization followed the corresponding characteristics of the subcategories. This and the keyword count allowed for assessing where the authors of the publications put their thematic emphasis (see Table 3).

The parameter analysis (Phase II.c) assessed the publications regarding (1) ES provided by soil functions and (2) soil-related ES provided by GI type. Therefore, we screened all publications to see if and how an analysis of the soil-related ES within the focus topics occurred (according to CICES - Common International Classification of Ecosystem Services [35]). A classification emerged during the parameter analysis,(see Table 3) which showed that the publications covered soil-related ES and soil quality rarely (Class 1), indirectly (Class 2), directly (Class 3), or mainly (Class 3). Based on this classification, a closer look at the assessment of the soil-related ES showed if only one ES was the main research topic or if the publication covered more ES provided by soil functions. Furthermore, we analyzed the publications for the provision of soil-related ES provided by individual GI types.

Then, the results of these analyses were discussed and synthesized to assess the representation of soil-related ES within GI-related publications.

\section{Results}

\subsection{General Analysis (Phase II.a)}

The analysis revealed that although we did not apply any restriction for the publication year, the publications included in the content analysis were published after the year 2008 (see Figure 2). The numbers of publications increased between 2013 and 2018. Of the 284 articles, 213 were published between 2016 and 2019. 


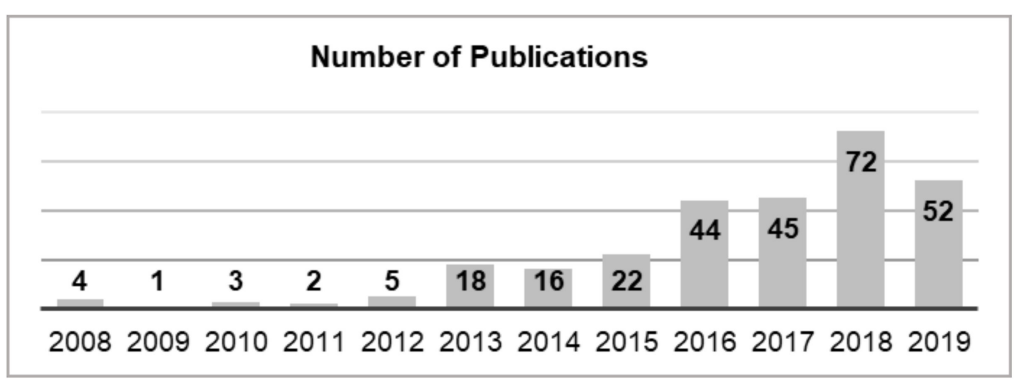

Figure 2. Number of included publications by year $(n=284)$.

The main publication areas around the globe are North America, Europe, Australia, and China, with less representation in the remaining parts of Asia, in South America, and in Africa (see Figure A1 and Table A1).

Less than one-third of the publications was published as an open access article (mean average $26 \%, n=284$ ). The total of the publications consists of 220 research articles (case studies, field studies, laboratory analyses), 52 reviews, and 11 review analyses.

\subsection{Thematic Distribution (Phase II.a)}

The starting point of the assessment of the thematic distribution was the main soil functions (see Introduction). However, the initial definition of soil functions [8] was soon very restrictive. To be able to assess all emerging topics, we expanded the themes to all soil-related ES. This revealed a dominant focus topic, namely stormwater management (soil functions: infiltration and retention) with $45 \%$ (see Figure 3 ). Other focus topics directly linked to chemical, physical, and biological soil functions were assessment of Ecosystem Services $14 \%$, biodiversity and habitats $10 \%$, nutrient storage $3 \%$, biomass and food $2 \%$, filtration and transformation $1 \%$, and carbon pool $1 \%$.

\section{Focus topics}

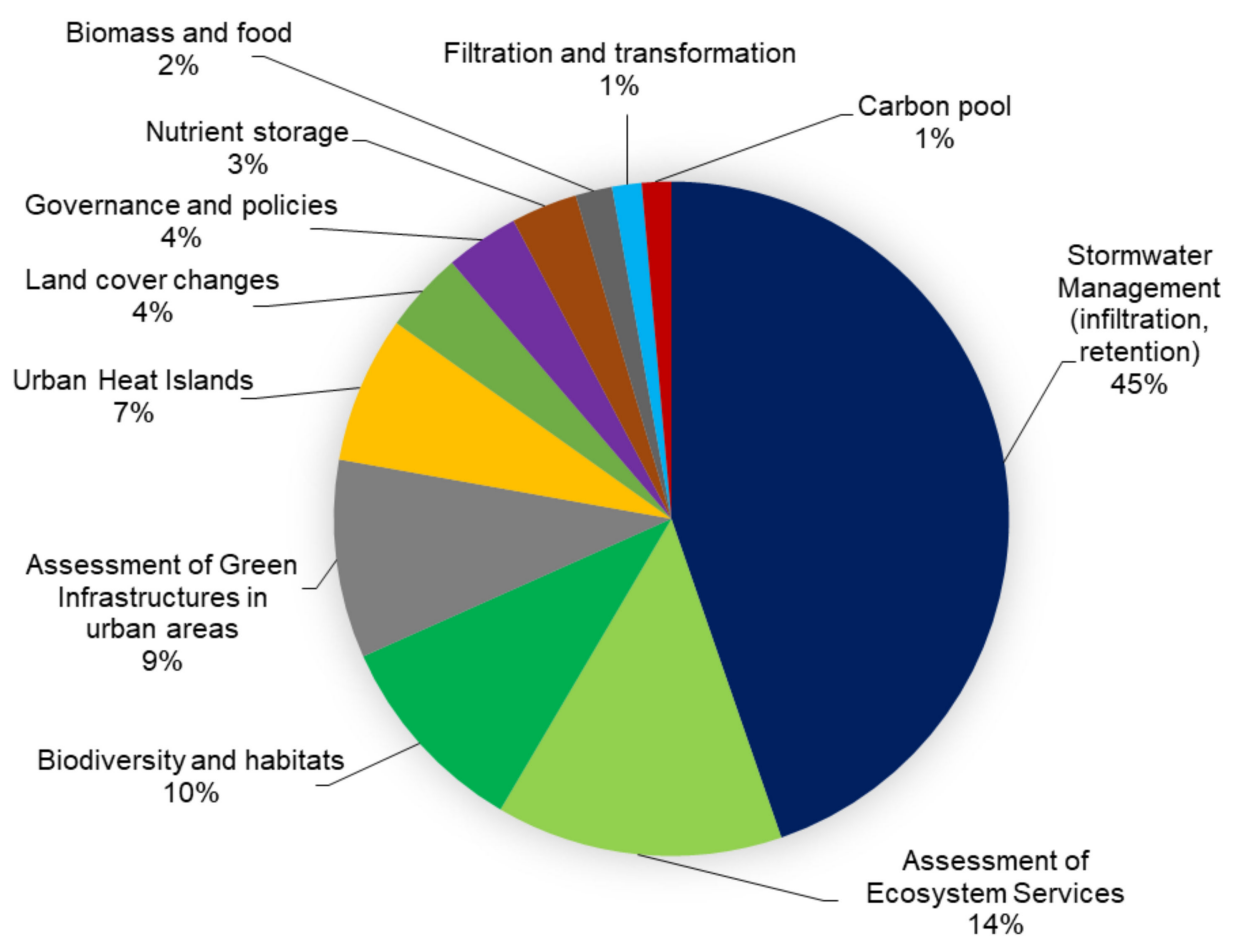

Figure 3. Thematic distribution according to the focus topics of the publications $(n=284)$. 
Additionally, the following topics emerged predominantly: assessment of Green Infrastructure in urban areas 10\%, Urban Heat Islands 7\%, land cover changes $4 \%$, and governance and policies $4 \%$.

Almost half of the publications focused on soil in the context of stormwater management, specifically physical functions such as infiltration, retention, and runoff [16-18,23,27,36-38]. Soil is of interest in the (peri-) urban GIs when it can help prevent natural hazards such as floods [39,40]. Fewer publications address land cover changes [6,41-43] or soil nutrients $[11,14,44]$. Furthermore, the inherent soil quality to sustain biodiversity, the gene or carbon pool is of less interest.

\subsection{Keyword Analysis (Phase II.b)}

The overview of the keywords highlights where the authors put the most importance in their research (e.g., GI types, water, systems) and where not (e.g., specific chemical, physical, and biological soil functions; see * in Table 2).

Table 2. Overview of keyword (sub-)categories, identified according to abundance (* indicates specific soil functions).

\begin{tabular}{|c|c|c|c|}
\hline Keyword Categories & Subcategories & $n^{\circ}$ of Publications & $\%$ \\
\hline \multirow{9}{*}{ Green Infrastructures and types } & Green Infrastructure, Green-Blue Infrastructure & 153 & 23 \\
\hline & Parks, forests, gardens & 44 & \\
\hline & Low-Impact Development (LID), Sustainable & & \\
\hline & Urban Drainage Systems (SUDS) & 43 & \\
\hline & Bioswale, raingarden & 17 & \\
\hline & Permeable surface & 14 & \\
\hline & Green surfaces, green space & 9 & \\
\hline & Green roofs and walls & 15 & \\
\hline & Catchment, water bodies & 8 & \\
\hline \multirow[t]{7}{*}{ Water } & Stormwater and runoff & 60 & 16 \\
\hline & Nutrient and water storage & * 49 & \\
\hline & Water management & 41 & \\
\hline & Filtration and transformation & * 35 & \\
\hline & Water treatment and quality & 12 & \\
\hline & Drainage & 10 & \\
\hline & Ecosystem Service related to any water topic & 3 & \\
\hline \multirow{5}{*}{$\begin{array}{c}\text { Sustainability and Systemic } \\
\text { boundaries }\end{array}$} & Climate change, resilience, and adaptation & 52 & 11 \\
\hline & Changing systems and trends & 31 & \\
\hline & Sustainability and sustainable development & 31 & \\
\hline & Systemic solutions, complexity and frameworks & 24 & \\
\hline & Ecosystems & 10 & \\
\hline \multirow[t]{3}{*}{ Spatial distribution } & Urban, urban density, built environment & 51 & 8 \\
\hline & Regional details & 33 & \\
\hline & Spatial distribution, land cover, land use & 17 & \\
\hline \multirow[t]{2}{*}{ Project details } & Methods used & 86 & 7 \\
\hline & Project name/set-up & 11 & \\
\hline \multirow[t]{3}{*}{ Policy and planning } & (Urban) planning and design & 40 & 7 \\
\hline & Management practices & 27 & \\
\hline & Policy/governance/strategies/regulations & 26 & \\
\hline Ecosystem Services & Ecosystem Services (in general) & 73 & 6 \\
\hline \multirow[t]{3}{*}{ Biodiversity } & Ecosystem Service: biodiversity and ecology & 42 & 6 \\
\hline & Plant traits/vegetation & 24 & \\
\hline & Biodiversity pool and habitats & * 12 & \\
\hline \multirow{3}{*}{ Assessment and indices } & Optimization, efficiency, evaluation, benefits & 27 & 5 \\
\hline & Economic variables, Life Cycle Assessments & 21 & \\
\hline & Assessment, scenarios, quality, impact & 20 & \\
\hline
\end{tabular}


Table 2. Cont.

\begin{tabular}{|c|c|c|c|}
\hline Keyword Categories & Subcategories & $n^{\circ}$ of Publications & $\%$ \\
\hline \multirow{4}{*}{ Sealing and restoration } & Soil pollution & 18 & 4 \\
\hline & Soil and soil sealing & 17 & \\
\hline & Restoration, reforestation, revegetation & 14 & \\
\hline & Demolition, reclaim, reuse, retrofit & 6 & \\
\hline \multirow[t]{3}{*}{ Carbon and emissions } & Micro-climate regulation & 29 & 4 \\
\hline & Carbon storage & * 11 & \\
\hline & Gas exchange, thermal, heat, energy, CO2 & 9 & \\
\hline \multirow[t]{2}{*}{ Social context } & Health and well-being, social aspects & 21 & 2 \\
\hline & Archive and heritage & * 1 & \\
\hline Biomass and materials & Biomass and food production & * 14 & 1 \\
\hline Nature-based solutions & Nature-based solutions & 14 & 1 \\
\hline
\end{tabular}

Most of the keywords addressed GI and specific GI types (23\%), followed by keywords regarding water issues such as stormwater and runoff or water treatment $(16 \%)$. Keywords regarding soil function loss or sealing $(4 \%)$ were rarely used. Even fewer keywords were used for health and well-being ( $2 \%)$, indicating that the social context is less important in publications regarding soil-related ES of GI measures, as were biomass and materials and Nature-based solutions ( $1 \%$ each). On the other hand, the identified keyword categories "systems and sustainability", "spatial distribution", and "policy and planning" were fairly common (in total $26 \%$ ).

\subsection{Parameter Analysis (Phase II.c)}

We conducted the parameter analysis to assess (1) how ES provided by soil functions were addressed in the publications and (2) for which GI measures. First, the publications were classified depending on how they addressed provisioning and regulating ES and soil quality, hence the multi-functionality of soil to sustain its environmental capacities. GI publications in Class 1 addressed soil quality and provisioning and regulating ES rarely $(n=47)$, in Class 2 indirectly $(n=85)$, in Class 3 directly $(n=130)$, and in Class 4 mainly $(n=22)$. The heat map (see Table 3 ) visualizes the thematic distribution of the topics, which are most prominent within the individual classes.

Table 3. Heat map visualization of the thematic distribution of the focus topics (number of publications) within each class $(n=284$, green $=$ high(er) value(s), white $=$ low(er) value(s)).

\begin{tabular}{ccccc}
\hline Focus topic & $\begin{array}{c}\text { Class 1: } \\
\text { Rarely }\end{array}$ & $\begin{array}{c}\text { Class 2: } \\
\text { Indirectly }\end{array}$ & $\begin{array}{c}\text { Class 3: } \\
\text { Directly }\end{array}$ & $\begin{array}{c}\text { Class 4: } \\
\text { Mainly }\end{array}$ \\
\hline Stormwater management & 12 & 26 & 86 & 3 \\
Assessment of & 5 & 22 & 9 & 3 \\
Ecosystem Services & 0 & 1 & 5 & 3 \\
Soil nutrients & 0 & 0 & 1 & 3 \\
Filtration and transformation & 8 & 7 & 10 & 3 \\
Biodiversity and habitats & 6 & 5 & 7 & 2 \\
Urban Heat Islands & 4 & 2 & 3 & 2 \\
Land cover changes & 0 & 2 & 1 & 1 \\
Biomass and food & 4 & 5 & 0 & 0 \\
Governance and policies & 6 & 15 & 6 & 0 \\
Assessment of GI & 2 & 0 & 2 & 22 \\
in urban areas & 47 & 85 & 130 & \\
Carbon pool & & &
\end{tabular}

The majority of peer-reviewed publications addressed soil quality in regard to the ES stormwater management. This includes the soil functions retention, runoff, flooding, and 
infiltration, mirroring the thematic distribution and the keyword analysis. When soil quality is directly addressed, the majority of publications still addressed water management. Soil quality is indirectly addressed when the topics stormwater management, the assessment of ES, and the assessment of GI in urban areas are covered.

\subsubsection{Evaluation of ES Provided by Soil Functions}

To assess the importance of the individual ES, such as water storage or biodiversity, provided by chemical, physical, and biological soil functions, we analyzed how they were addressed in the publications (see Figure 4).

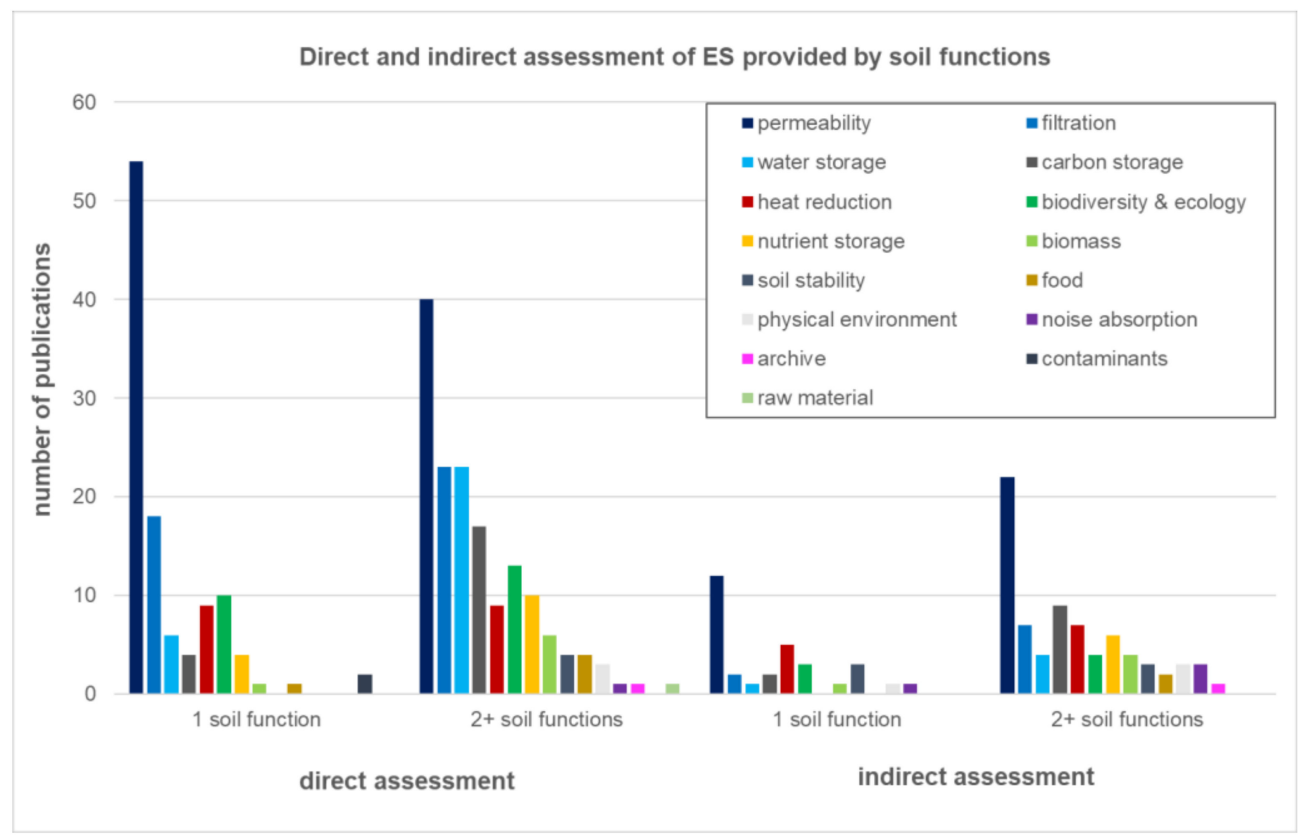

Figure 4. Number of publications with direct or indirect assessment of Ecosystem Services (ES) provided by soil functions $(n=237)$.

In 48 publications, soil was only mentioned as part of the GI system, but no specific soil function or soil-related ES were addressed or further discussed, which reduced the number of included publications to 237. We rated the soil-related ES as "directly" or "indirectly assessed", respectively, depending on how in-depth one or more soil functions (e.g., permeability, nutrient storage) were explored.

The top three ES discussed relevant GIs focusing on soil in the context of water, specifically the soil functions permeability and infiltration (128), filtration (pollution) (41), and water storage (29). Topics regarding e.g., noise absorption or soil contaminants have hitherto been of less interest to the research community. In $86 \%$ of the publications, which addressed more than one soil function directly, two or three soil functions were of interest to the authors (see Table A2).

\subsubsection{Assessment of the ES Provided by GI Types}

GI types provide a variety of ES (see Figure 5); 91 publications did not mention any ES for specific GI measurements, which reduced the number of included publications to 203. 


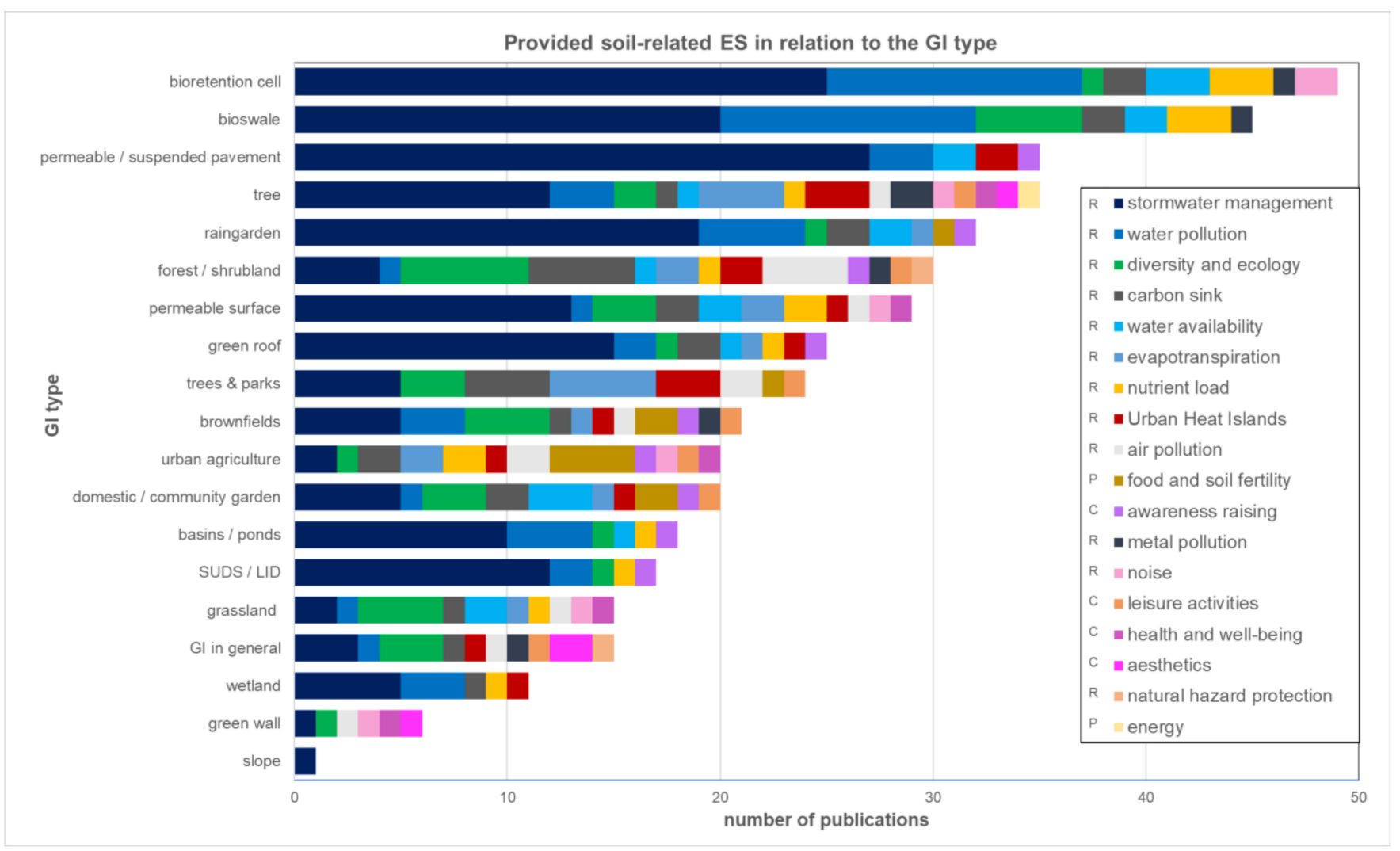

Figure 5. Overview of the provided ES (R-Regulating, C-Cultural, P-Provisioning ES) in regard to the Green Infrastructure (GI) type ( $n=203$; SUDS = Sustainable Drainage Systems, LID = Low-Impact Development).

Figure 5 shows which ES are of main interest for which type of GI. In total, 186 $(65.5 \%)$ and $54(19.0 \%)$ publications, respectively, discussed stormwater management and the treatment of polluted water. The main GI measures in this context are permeable or suspended pavements, bioretention cells, bioswales, and raingardens. Although almost no publication addressed soil as part of green roofs as a key topic (see Table 2), the water retention capacity of green roofs and therefore the benefit for stormwater management was acknowledged in $12(4.2 \%)$ publications. Biodiversity was the third most common ES and was addressed in 41 (14.4\%) publications; these mentions were almost fairly distributed over all GI types. As outlined in the previous analyses, cultural ES are less frequently discussed.

\subsection{Past and Future Trends of Soil-Related ES in GI Measures}

Most of the publications included in this systematic review were published after the year 2013, and 75\% were published in only four years from 2016 to 2019 (see Figure 2). This can be explained with the emergence of the term "Green Infrastructure", which is a key search term for this review, in the 1990s in the USA and its later worldwide usage at the beginning of the early 2000s, especially since the publication of the EU Green Infrastructure Strategy in 2013 [45,46]. Furthermore, authors from the US published more than one-quarter of all included publications (see Figure A1). The global distribution of publications showed a clear emphasis in North America, China, and Europe (see Figure A1), correlating with the publication of GI strategies, especially focusing on soil-related ES such as stormwater management $[28,36,46]$.

According to the analysis, not all soil-related ES in GI measures are represented equally. In general, the publications rarely addressed soil quality directly (22), but focused on specific physical and chemical soil functions more extensively (e.g., water infiltration and retention). Other soil-related ES were hardly addressed at all. The parameter analysis 
assessed the focus topics in regard to how comprehensively the research addressed soil quality in terms of sustaining the multi-functionality of soil (see Table 3). It became evident that soil is fairly equally mentioned over all focus topics when it is either rarely considered (Class 1) or the main topic (Class 4). Publications addressed almost exclusively ES related to water when specific soil-related ES were addressed indirectly (Class 2) or directly (Class 3). The same focus was confirmed when only chemical, physical, and biological soil functions were considered. Water-related soil functions, such as permeability, infiltration, filtration, and water storage, were either directly or indirectly the most pronounced research interests (see Figure 4). Usually, publications addressed two or more soil-related ES rather than just one ES, indicating the interconnection of all soil functions.

Five other chemical, physical, and biological soil function categories were common enough to become a focus topic (biodiversity, soil nutrients, biomass, filtration and transformation, carbon pool). Even when combined, they only amounted to $16 \%$ of all publications, compared to $38 \%$ of all publications focusing on no specific soil-related ES but other themes (e.g., assessment of ES or governance and policies) (see Figure 3). The extended keyword analysis during the content analysis revealed the same priorities: Soil as a keyword was rarely mentioned, showing that specific GI types were more important to the authors (see Table 3). The keyword categories "sustainability and systemic boundaries", "spatial distribution", and "policy and planning" emerged fairly commonly (in total $26 \%$ ), showing the importance of policy planning and implementation for GI in urban settings [30,47-49]. As the initial literature search ended on August 21, 2019, we used the same search terms for a post-process control search. This exposed 308 new publications until December 31, 2020. A short analysis revealed that 94 publications would pass the screening phase I.b (Title and keyword screening) and confirmed the overall trends in regard to the focus topics. Water-related issues are still the most common topics (stormwater management $38 \%$, filtration and transformation $12 \%$ ), but the assessment of GI increased in importance $(21 \%)$.

\section{Discussion}

\subsection{Representation of Soil-Related ES in GI Measures}

The provision of ES is the second most common focus topic and is included as an additional theme in many other focus topics as well (e.g., biodiversity, Urban Heat Islands (UHI); see Figure 3). The most commonly provided ES were stormwater management, nutrient load, and water pollution (see Figure 5). However, Blanchart [4] identified at least 17 targeted ES urban soils can provide, of which all can be translated to ES potentially provided by GI.

Urban soil characteristics are very heterogenous and vary within individual cities as well as individual properties [13]. The soil conditions of a roadside bioretention swale in the city center will differ from a vacant lot in the peripheral regions of a city. The urban soil development behaves according to pedogenesis as any other soil type and changes over time [50]. Hence, a plot of soil can provide various ES as the soil adapts over time. lications.

The following subsections reflect the (most) crucial ES addressed in the analyzed pub-

\subsubsection{Stormwater Management}

Stormwater management was the ES topic of most interest to the scientific community researching GI measures when also including the aspect of soil (see Figure 3), although GI measures are designed to fulfill different purposes and ES. The analysis (see Figure 5) revealed that the most studied GI measures in regard to the ES provision were bioretention cells, bioswales, permeable or suspended pavements, trees, and raingardens. However, for all GI measures, there was at least one publication mentioning the effects of stormwater management (see Figure 5), even if the GI measures have inherently a minor focus on stormwater management, such as urban agriculture or green walls. 
Stormwater management measures reduce the total amount of sealed soil area, allowing for enhanced rainwater infiltration. Groundwater can be replenished, and the pressure on the urban sewage and drainage systems is lightened [51]. As GI has a mitigating effect on extreme weather events, such as heat waves and floods, this became an increasingly important topic over the last ten years (see Figure 2). Especially in the USA (14.3\%, see Table A2) and China (4.3\%), stormwater management was put in the center of interest within the Green Infrastructure Agendas in the US in 2008, 2011, and 2013 [52], and within the Sponge City concept in China in 2013 [36].

In the US, research focused on individual GI measures and their effects on the urban water cycle $[38,53,54]$. Life cycle analyses of raingardens [38,55], swales, and permeable surfaces [53] compared to gray infrastructure alternatives confirmed once more that GI measures can be highly effective, depending on their intended usage. A combination of systems promises the best overall results for the preservation of urban ecosystems [53]. The concept of Green Stormwater Infrastructure, which is also called Low-Impact Development (LID) or Sustainable Urban Drainage System (SUDS; more often used in the UK), started originally in the US to use GI measures for stormwater management purposes and is now implemented worldwide [56]. The idea of LID is to install natural, small-scale drainage measures to infiltrate, retain, and clean urban runoff locally [56].

In China, the government promotes the strategy of a Sponge City, which is a new concept for integrated urban water management to enhance the cities' resilience and manage quantitatively and qualitatively the average rainfall on-site [36]. The idea is to implement various GI measures combined with gray infrastructure to clean, harvest, and use rainwater, recharge groundwater, reduce peak flow and runoff, and transfer the water out of the city if needed $[17,36]$. These efforts shall help control floods as well as to foster ecological restoration [17]. However, the concept has to overcome technical (lack of experts, appropriate land and materials), financial (lack of funding or economical life cycle analyses) and regulatory (lack of integration in urban land policy or legislative mandate) challenges before it can be successfully implemented at the local level [57].

Studies on a more local level focused on individual GI measures. Permeable surfaces slow down the flow velocities and lower the flood risk, which helps to relieve the urban sewer systems and leads to fewer costs for municipal sewer systems [58]. The efficiency of the hydraulic performance of permeable pavements is remarkable as it can reduce flood events by $70 \%$ and peak flow by $95 \%$ [37].

Trees greatly influence the urban rainwater cycle via canopy interception loss, evapotranspiration, and increased infiltration rates when planted in tree pits along with sealed infrastructure [59]. Trees also change the hydraulic conductivity of vegetated soil, which is more uniform with higher rainfall depths and more heterogenous in drier periods, as the hydraulic conductivity increased when shredded leaves cover the grass [23]. The combination of GI measures with trees can enhance the effectiveness of stormwater management efforts due to the higher infiltration rate, water storage capacity, transpiration rate and, therefore, the overall water output [59]. The health of trees and their performance depends on the GI design and the soil's water retention capability as well as the overall water availability [60].

Publications on stormwater management not only covered explicit soil functions, such as infiltration or retention, but also expanded the focus on other aspects. Other research focused on the optimal location of GI measures for stormwater management [61], the effect of the individual design of the GI measures on their soil and microbial properties [27], or the provided ES by Green Stormwater Infrastructures [18]. Of interest in regard to raingardens was the combination of stormwater retention and food production [16] as well as the maintenance efforts and technical design of a sewer connection [58]. This list of aspects shows the vast interest of the researchers to investigate a wide range of interconnections stormwater management efforts can have on the local and global scale. To enhance participation for the implementation of new GI measures in the area, the 
experiences of citizens with extreme weather events and the effects on their personal life (e.g., flood events and destroyed streets) can be utilized to reduce barriers to action [62].

\subsubsection{Regulation of Water Quality}

Soil as a beneficial medium to reverse and retain water pollution of contaminants or nutrient overloads is one of the most commonly researched soil-related ES (see Figure 4) and the second most investigated aspect of ES for individual GI measures, especially bioswales (or vegetation swales) and bioretention cells (see Figure 5).

In general, permeable surfaces increase the infiltration of contaminated runoff and decrease the discharge of contaminants and water to the drainage system $[15,63,64]$. This is also possible by retrofitting impervious surfaces with permeable pavements and bioretention cells, reducing the runoff pollution load at the same or even lower costs compared to conventional infrastructure measures [63]. According to Anderson et al. [54], bioswales along parking lots were able to reduce the overall toxicity and the contaminant load of stormwater ( $81 \%$ reduction for suspended solids and metals, $82 \%$ reduction for hydrocarbons, $74 \%$ reduction for pyrethroid pesticides). A combination of stormwater management measures such as subsurface pipes, wetlands, and further filtration layers can remove up to $80 \%$ of suspended solid and heavy metals [43].

Frosi et al. [15] and Morash et al. [65] found evidence for large volumes of runoff along streets in urban areas to have higher concentrations of contaminants, which affects the soil and the biogeochemical processes within the soil body. This can negatively affect tree growth due to the accumulation of contaminants, such as de-icing salt, in the soil layer [66]. Surprisingly, a study in New York City found no significant high contamination levels of topsoil samples in younger GI sites, which was probably because the GI measures (enhanced tree pits, vegetation swales, and street-side infiltration swales) were designed for stormwater purposes and, therefore, a higher contamination load [27]. It is essential to adapt GI measures referring to substrate performance for the intended purpose to increase the pollution removal capacity [67] and to avoid trade-offs between stormwater management and vegetation growth [66].

Plants do not only increase the performance of the hydraulic conductivity and the permeability of bioretention systems but also the nitrogen removal capacity [68]. Nidzgorski and Hobbie [69] discovered the significantly aggregated effect of urban trees for the reduction of nutrient leaching to the groundwater (especially phosphorus), contributing to likewise significant cost savings because of the reduced removal workload for the drainage plants. Compared to vegetation swales and street-side infiltration swales, enhanced tree pits had a higher level of microbial biomass carbon and nitrogen content, which suggest that these GI measures function as denitrification hotspots to lower the nitrogen export to urban watersheds [27]. Street tree pits can decrease the mass flux of contaminants with increasing depth and increasing soil organic matter content, and therefore, functioning as bioretention cells [15]. The overall water quality of the stormwater management system will benefit with increasing depth of the filter media and a plant selection with higher uptake potential for nutrients [12].

\subsubsection{Diversity and Ecology}

Biodiversity and connectivity ES of green spaces seem to be increasing in importance, as ecology was part of the analyses for 16 of the listed GI measures (see Figure 5). The design of and plant selection in urban grasslands does not only influence the presence and quantity of aboveground fauna species and habitat conditions but also the composition of belowground soil microbes [70]. In bioretention cells, the biological activity and soil organic matter decreases with depth within the soil profiles [50]. The microbial community (bacteria, fungi, and invertebrates) varied due to the plant species at the soil surface $(0-10 \mathrm{~cm})$ and due to the plant height in deeper soils $(11-20 \mathrm{~cm})$ [70]. Bioswales function as a source for a diverse and active bacterial soil community, fostering biogeochemical cycling and pollution removal [71]. Even younger GI sites (>10 years) showed high belowground 
microbial activity, which is essential for carbon and nitrogen cycling and, therefore, plant growth [27].

The restoration of grasslands at urban-industrial sites can enhance biodiversity in a very short time with the application of propagules despite initial constraining abiotic and biotic soil conditions [72]. Hereafter, the consideration of ecological parameters is important and needs to be considered for maintenance purposes [50]. More diverse perennial urban meadows create substantial benefits for the above and below ground biodiversity compared to short mown grassland, while reducing maintenance intensity [70]. This is directly linked to soil quality. However, the authors point out that the thoughtful consideration of coexisting meadow types for sustainable landscape design has been rarely considered when planning urban green spaces. It requires adaptable and more complex mowing regimes and a focus on public communication to transfer the intent of the various meadow types [70] and their potential to raise or restore belowground biodiversity and connectivity, and thus soil quality.

\subsubsection{Climate Change Adaptation and Mitigation}

Only in $2 \%$ of the here analyzed publications was ES referring to climate change adaptation and mitigation or regulation capacities of soil the focus topic (carbon pool 1\% and UHI 1\%, see Figure 3). The potential of soil to actively contribute to climate change adaptation measurements (as appreciated in Lal et al. [73] and Amelung et al. [74]) is not yet widely acknowledged in GI research. However, climate change adaptation (reduction of UHI, increased evapotranspiration) and the mitigation potential of soil (carbon sink, see Figure 5) are analyzed as an integral part of the GI types such as individual trees, parks, shrublands, and forests in comparison to other ES [7,12,19,75,76].

Despite the assumption that, on a macro scale, soils within city limits might be especially degraded, impervious, and biologically basically inactive [5], on a micro scale, urban soil can sequester significant amounts of Soil Organic Carbon (SOC) [11]. Urban soil can act as a higher carbon sink than adjacent rural soil [11] and store similar mean soil C and $n$ levels to forests and agricultural soils [13]. Larger GI measures such as afforestation projects should adjust to more natural vegetation structures with shrubs and trees because the organic amendments can result in smaller N20-fluxes from the soil, keeping the carbon and nitrogen cycles internal [14]. Interestingly, Shrestha et al. [12] proposed the opposite for bioretention cells along roadsides, which can also be a net sink for carbon and nitrogen. Their results suggested that a reduction of the amount of organic matter or a greater C:n ratio, as well as an increase of volume of the filter media, will enhance the contribution for climate change mitigation. Nutrient re-release could be reduced with a plant selection focusing on low litter (biomass) production [12].

It is widely appreciated that urban green spaces largely contribute to the mitigation of UHI with plants and unsealed soil [20,77], and the process is mainly indifferent to varying conditions in the land area or soil type [7]. Implications for the local scale to reduce UHI cannot yet be made effectively [78], as most studies have been concentrating on higher scales. For example, urban lawns and shading trees are highly effective in reducing UHI and saving building energy, especially in more arid regions, on the small scale [76]. However, single and locally restricted GI measures would most likely not reduce extreme heat events significantly, as the cooling effect is increased by the size, geometry, and spread of the green and blue space networks [79,80]. Lin et al. [20] confirmed the importance of a carefully designed, strategic plan for the distribution of GI measures in residential areas, parks, and along roadsides to fully harness the cooling potential of vegetation. When considering retrofitting, existing or installing new urban green spaces to mitigate UHI, the soil heat flux is a key factor to modulate the microclimatic conditions important for evapotranspiration as well as plant growth and carbon assimilation [19]. 


\subsubsection{Social Aspects and Cultural ES}

Cultural ES include benefits such as aesthetics, health and well-being, social interactions, and leisure activities [81]. In this review, rarely any publications covered cultural ES in regard to soil and GI measures (see Table 2 and Figure 5), which is not very surprising, as these effects were relatively rarely researched in general $[82,83]$. However, the included research studies directly or indirectly considered soil as a parameter, as without soil, ES provided by GI would not be available.

Some beneficial aspects mentioned in the here analyzed literature were reduced stress, increasing relaxation, improvement of physical health, or faster recovery at hospitals with tree views [82]. For example, human thermal comfort can be significantly improved by trees and urban lawns because the increase in relative humidity counteracts loss of humidity from the human skin [76]. On an urban public square, the adaptation of the number of trees and their placement to the wind flow situation can increase the thermal comfort, which will improve further with the addition of open grass meadows [84].

Prudencio and Null [18] and Setälä et al. [5] emphasized the importance of the quantification of all ES, also social and cultural benefits, for easier integration into policy agendas.

\subsection{Soil Function Loss in the Context of GI Measures}

Soils in urban areas are often reduced to one or two of the functions they could potentially be providing, as e.g., support site for infrastructure [47]. When soil is sealed, all other soil functions get lost. However, the replacement of sealed soil with permeable surfaces will always restore some of the essential ES for humans and nature and contribute to the development of GIs [6]. This topic is rather scarcely covered in research on GI, as the analysis of the keywords showed that only $4 \%$ of all keywords addressed soil sealing and restoration.

The restoration of brownfields can reduce net soil loss and enhance the global natural capital [6]. To improve the soil properties, various soils can be transported from close-by locations [13] or even be mixed with municipal waste (construction waste, bio-stabilized material, recycled bentonites, and topsoil) to generate new Technosols with low ecological risk to the environment and humans, and to secure soil functions [85]. The use of constructed or reconstituted soils or technical substrates can compensate for lost ES and provide new ones [27]. The approach to use Technosols for remediation purposes impacts climate change adaptation efforts positively as waste products are reused and the soil materials act as carbon sequestration sinks and water retention areas [85]. In addition, trees planted in GI systems with structural soils or Technosols tend to survive longer and stay healthier than in regular tree pits while also reducing common conflicts between gray infrastructure and tree roots [59]. If for any reason, vegetated GI measures are not an option [37], even permeable surfaces without vegetation mitigate rainwater events efficiently.

The assessment of GI in (peri-) urban areas and the implementation of governance regulations and policies regarding soil cumulates to $14 \%$ of the focus topics within this review study (see Figure 3), showing the need to still assess the value of implemented GI measures and the aspect of soil in the future. When considering land use changes, the specific soil characteristics and functions need to be included in any policy decision [5]. Salvati et al. [86] could not find a significant link between lower quality landscape (e.g., artificial surfaces) and higher consumption of land per capita, suggesting that urban planning does not take the landscape or soil quality into account adequately for its planning decisions. This again demonstrates the discrepancy between soil researchers and urban planners, as urban soil quality and especially soil contaminants for human health are of main interest to the soil research community [87].

Soil and land use decisions are more often based more on the site location than on the intrinsic soil quality [47], which could be averted if soil is part of sustainable urban land valuation [88]. The authors suggest a system for decision-making in urban planning, which assesses not only the physical and chemical properties but also includes intangible factors (e.g., social value, aesthetics) to assure a sustainable usage of scarce urban soil resources. 
GI measures are more likely to be installed if they are part of an overall urban sustainability policy or initiative and linked to urban development projects [43]. Blanchart et al. [4] developed a decision support system (DESTISOL) to enable soil scientists and urban planners to work together with an urban soil quality assessment, which links soil indicators, soil functions, soil covers, and soil ES. The soil of brownfields or vacant lots is not always fully degraded and can fulfill many soil functions [13]. So far, the tool DESTISOL is based on the redevelopment of urban brownfields, but with further assessments and collaborations, it can be applied to various fields and other GIs [4].

The inclusion of GI measures into regional planning strategies has the potential to confine soil sealing and to promote green spaces within urban areas [86], as the protection of naturally developed soils is always to be preferred to unsealing previously covered surfaces [6].

\subsection{Limitations of this Review}

Although this review was conducted as a systematic literature review, due to the inclusion and exclusion criteria, not all publications on green infrastructure and soil available during the defined time frame were considered. As this review is based on scientific publications, a limitation of the review can be assumed in the incomplete representation of projects and interventions made at a very local scale. Any form of gray literature was not included. This could impair the comprehensive assessment of the broader performance of GI in delivering ES.

Additionally, the term "soil" as used in our study could overlap the broader term "land", which is probably commonly used in the context of GI. We intentionally excluded the term "land" from the keyword search, as the focus of this review is specifically on soil, soil-related ES, and soil quality. However, peer-reviewed publications on land management, which consider land in a three-dimensional way, will assess the below-ground area and refer to it as "soil" at least once. In this case, we assume such publications to be covered in the identification and screening phase of our systematic search process.

In this review, publications were only included if natural grown soil was used or added to technical substrates for the GI measures. However, in assessing the ES of each GI measure, we did not differentiate between naturally grown soil, Technosols, and technical substrates. We suggest this to be addressed in a further review as natural grown soil can potentially provide even more ES.

\section{Conclusions}

In this article, we assessed how peer-reviewed publications on Green Infrastructures (GI) represented soil-related Ecosystem Services (ES). In the reviewed publications, the representation focused heavily on the contribution of soil to stormwater management, with an emphasis on the specific soil functions permeability, infiltration, and filtration. The GI measures bioretention cells, bioswales, and permeable or suspended pavements were the most commonly researched GI types.

Other focus topics, such as biodiversity, habitats, and the assessment of ES or GI in urban areas were of less interest to the research community focusing on GI in urban areas. The extended content analysis revealed that regulating and provisioning ES were far more often researched than cultural ES. It is widely acknowledged that GI measures provide valuable benefits for nutrient retention, pollutant removal, and climate mitigation, such as reduction of $\mathrm{UHI}$, improvement of the microclimate, and carbon storage.

Further on, we investigated the peer-reviewed publications on GI in regard to the loss of soil-related ES and soil functions. It became evident that the assessment of soil functions in terms of substrate functionality and compensation for the loss of soil-related ES has not yet been covered extensively in GI research publications. The contribution of GI soil and restoration of sealed surfaces to climate adaptation measures seems underutilized but has promising potentials when soil quality aspects become an inherent part of GI measures. 
Author Contributions: P.M. was the main author of the article, supervised by R.S., who was also strongly involved in the structuring process of the paper. All authors have read and agreed to the published version of the manuscript.

Funding: Open access funding was provided by BOKU Vienna Open Access Publishing Fund.

Institutional Review Board Statement: Not applicable.

Informed Consent Statement: Not applicable.

Data Availability Statement: No new data were created or analyzed in this study. Data sharing is not applicable to this article.

Conflicts of Interest: The authors declare no conflict of interest.

\section{Appendix A}

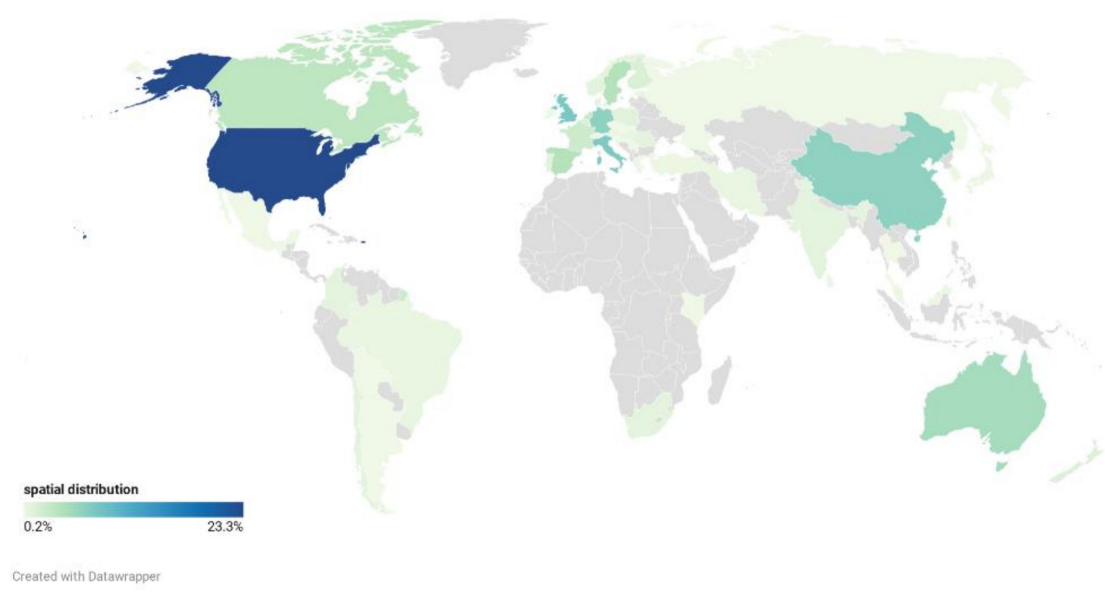

Figure A1. Spatial distribution of author's country affiliation $(n=403)$.

Table A1. Ranking of the author's country affiliation according to (1) the total number of authors $(n=403)$ and (2) the affiliation of the main author $(n=284)$.

\begin{tabular}{cccc}
\hline Ranking & Country & \multicolumn{2}{c}{ Country Affiliation } \\
\hline & & All Authors [\%] & Main Author [\%] \\
\hline 1 & USA & 23.3 & 28.2 \\
2 & United Kingdom & 7.7 & 6.3 \\
3 & Italy & 7.4 & 8.1 \\
4 & China & 6.5 & 6.7 \\
5 & Germany & 6.5 & 6.0 \\
6 & Australia & 5.0 & 5.6 \\
7 & Spain & 4.0 & 4.6 \\
8 & Sweden & 4.0 & 3.2 \\
9 & Canada & 3.5 & 3.5 \\
10 & The Netherlands & 3.0 & 2.1 \\
\hline
\end{tabular}

The distribution varies if only the main author is considered. If the analysis focuses on the main author, and therefore the driving force behind the research, Italy is the second and China is the third most common country to address GI in paper publications (see Table 2). In $75.7 \%$ of the publications, the authors came from only one country; in $16.5 \%$, the authors came from two countries, and the remaining $7.7 \%$ of the articles were published by authors from three to eight countries. 
Table A2. Spatial distribution of the focus topics ( $n=399$, all author contributions for every focus topic).

\begin{tabular}{|c|c|c|c|c|c|c|c|c|c|c|c|c|}
\hline$\%$ & $\begin{array}{c}\text { Stormwater } \\
\text { Management } \\
\text { (Infiltration, } \\
\text { Retention) }\end{array}$ & $\begin{array}{l}\text { Eco-System } \\
\text { Services }\end{array}$ & $\begin{array}{l}\text { Biodiversity } \\
\text { and Ecology }\end{array}$ & $\begin{array}{l}\text { Assessment of } \\
\text { Green } \\
\text { Infrastructures } \\
\text { in Urban } \\
\text { Areas }\end{array}$ & $\begin{array}{l}\text { Urban Heat } \\
\text { Islands }\end{array}$ & $\begin{array}{l}\text { Governance } \\
\text { and Policies }\end{array}$ & $\begin{array}{l}\text { Land Cover } \\
\text { Changes }\end{array}$ & $\begin{array}{l}\text { Biomass and } \\
\text { Food }\end{array}$ & Soil Nutrients & Carbon Pool & $\begin{array}{l}\text { Filtration and } \\
\text { Transformation }\end{array}$ & $\%$ TOTAL \\
\hline USA & 14.3 & 1.5 & 2.3 & 0.5 & 1.5 & 0.3 & 0.3 & 0.3 & 2.0 & 0.3 & 0.5 & 23.6 \\
\hline UK & 2.5 & 1.0 & 1.0 & 1.0 & 0.5 & 0.8 & 0.8 & 0.3 & & & & 7.8 \\
\hline Italy & 1.8 & 2.0 & 0.5 & 1.5 & 0.3 & 0.8 & 0.5 & 0.3 & & & & 7.5 \\
\hline China & $\begin{array}{l}4.0 \\
4.3\end{array}$ & 1.0 & 0.0 & 0.3 & 0.8 & & & & 0.3 & & & 6.5 \\
\hline Germany & 0.8 & 1.5 & 1.5 & 0.5 & 0.8 & 0.3 & 0.5 & 0.8 & & & & 6.5 \\
\hline Australia & 2.3 & 0.8 & 0.3 & 0.3 & 0.8 & 0.3 & & 0.3 & & 0.3 & & 5.0 \\
\hline Spain & 0.8 & 1.5 & & 0.8 & & & 0.5 & & & 0.3 & 0.3 & 4.0 \\
\hline Canada & 1.0 & 0.3 & 0.5 & 0.5 & 0.5 & & 0.3 & & & & 0.3 & 3.3 \\
\hline NED & 0.8 & 0.8 & & 0.3 & 0.3 & 0.8 & 0.3 & & & & & 3.0 \\
\hline France & 1.3 & 0.5 & 0.3 & 0.3 & & & & 0.3 & & & & 2.5 \\
\hline
\end{tabular}




\section{References}

1. UN-Habitat. Cities and Climate Change: Global Report on Human Settlements, 2011; Earthscan: London, UK; Washington, DC, USA, 2011. [CrossRef]

2. Maes, J.; Teller, A.; Nessi, S.; Bulgheroni, C.; Konti, A.; Sinkko, T.; Tonini, D.; Pant, R. Mapping and Assessment of Ecosystems and Their Services: An EU Ecosystem Assessment; Publications Office of the European Union: Luxembourg, Luxembourg, 2020. [CrossRef]

3. Morel, J.L.; Chenu, C.; Lorenz, K. Ecosystem Services Provided by Soils of Urban, Industrial, Traffic, Mining, and Military Areas (SUITMAs). J. Soils Sediments 2015, 15, 1659-1666. [CrossRef]

4. Blanchart, A.; Séré, G.; Johan, C.; Gilles, W.; Stas, M.; Consalès, J.N.; Morel, J.L.; Schwartz, C. Towards an Operational Methodology to Optimize Ecosystem Services Provided by Urban Soils. Landsc. Urban Plan. 2018, 176, 1-9. [CrossRef]

5. Setälä, H.; Bardgett, R.D.; Birkhofer, K.; Brady, M.; Byrne, L.; de Ruiter, P.C.; de Vries, F.T.; Gardi, C.; Hedlund, K.; Hemerik, L.; et al. Urban and Agricultural Soils: Conflicts and Trade-Offs in the Optimization of Ecosystem Services. Urban Ecosyst. 2014, 17, 239-253. [CrossRef]

6. Tobias, S.; Conen, F.; Duss, A.; Wenzel, L.M.; Buser, C.; Alewell, C. Soil Sealing and Unsealing: State of the Art and Examples. L. Degrad. Dev. 2018, 29, 2015-2024. [CrossRef]

7. Murata, T.; Kawai, N. Degradation of the Urban Ecosystem Function Due to Soil Sealing: Involvement in the Heat Island Phenomenon and Hydrologic Cycle in the Tokyo Metropolitan Area. Soil Sci. Plant Nutr. 2018, 64, 145-155. [CrossRef]

8. European Commission. Communication from the Commission to the Council, the European Parliament, the European Economic and Social Committee and the Committee of the Regions: Thematic Strategy for Soil Protection COM(2006)231; European Commission: Brussels, Belgium, 2006.

9. Bünemann, E.K.; Bongiorno, G.; Bai, Z.; Creamer, R.E.; De Deyn, G.; de Goede, R.; Fleskens, L.; Geissen, V.; Kuyper, T.W.; Mäder, P.; et al. Soil Quality-A Critical Review. Soil Biol. Biochem. 2018, 120, 105-125. [CrossRef]

10. Karlen, D.L.; Andrews, S.S.; Weinhold, B.J.; Doran, J.W. Soil Quality: Humankind's Foundation for Survival. J. Soil Water Conserv. 2003, 58, 171-179.

11. Wang, Q.; Wang, W.; He, X.; Zhou, W.; Zhai, C.; Wang, P.; Tang, Z.; Wei, C.; Zhang, B.; Xiao, L.; et al. Urbanization-Induced Glomalin Changes and Their Associations with Land-Use Configuration, Forest Characteristics, and Soil Properties in Changchun, Northeast China. J. Soils Sediments 2019, 19, 2433-2444. [CrossRef]

12. Shrestha, P.; Hurley, S.E.; Carol Adair, E. Soil Media $\mathrm{CO}_{2}$ and $\mathrm{N}_{2} \mathrm{O}$ Fluxes Dynamics from Sand-Based Roadside Bioretention Systems. Water 2018, 10, 185. [CrossRef]

13. Herrmann, D.L.; Shuster, W.D.; Garmestani, A.S. Vacant Urban Lot Soils and Their Potential to Support Ecosystem Services. Plant Soil 2017, 413, 45-57. [CrossRef]

14. Pierre, S.; Groffman, P.M.; Killilea, M.E.; Oldfield, E.E. Soil Microbial Nitrogen Cycling and Nitrous Oxide Emissions from Urban Afforestation in the New York City Afforestation Project. Urban For. Urban Green. 2016, 15, 149-154. [CrossRef]

15. Frosi, M.H.; Kargar, M.; Jutras, P.; Prasher, S.O.; Clark, O.G. Street Tree Pits as Bioretention Units: Effects of Soil Organic Matter and Area Permeability on the Volume and Quality of Urban Runoff. Water. Air. Soil Pollut. 2019, 230, 1-14. [CrossRef]

16. Richards, P.J.; Williams, N.S.G.; Fletcher, T.D.; Farrell, C. Can Raingardens Produce Food and Retain Stormwater? Effects of Substrates and Stormwater Application Method on Plant Water Use, Stormwater Retention and Yield. Ecol. Eng. 2017, 100, 165-174. [CrossRef]

17. Jia, H.; Wang, Z.; Zhen, X.; Clar, M.; Yu, S.L. China's Sponge City Construction: A Discussion on Technical Approaches. Front. Environ. Sci. Eng. 2017, 11, 18. [CrossRef]

18. Prudencio, L.; Null, S.E. Stormwater Management and Ecosystem Services: A Review. Environ. Res. Lett. 2018, 13. [CrossRef]

19. Smalls-Mantey, L.; DiGiovanni, K.; Olson, M.; Montalto, F.A. Validation of Two Soil Heat Flux Estimation Techniques against Observations Made in an Engineered Urban Green Space. Urban Clim. 2013, 3, 56-66. [CrossRef]

20. Lin, B.B.; Meyers, J.; Beaty, R.M.; Barnett, G.B. Urban Green Infrastructure Impacts on Climate Regulation Services in Sydney, Australia. Sustainability 2016, 8, 788. [CrossRef]

21. Artmann, M.; Sartison, K. The Role of Urban Agriculture as a Nature-Based Solution: A Review for Developing a Systemic Assessment Framework. Sustainability 2018, 10, 1937. [CrossRef]

22. Grey, V.; Livesley, S.J.; Fletcher, T.D.; Szota, C. Establishing Street Trees in Stormwater Control Measures Can Double Tree Growth When Extended Waterlogging Is Avoided. Landsc. Urban Plan. 2018, 178, 122-129. [CrossRef]

23. Gadi, V.K.; Tang, Y.-R.; Das, A.; Monga, C.; Garg, A.; Berretta, C.; Sahoo, L. Spatial and Temporal Variation of Hydraulic Conductivity and Vegetation Growth in Green Infrastructures Using Infiltrometer and Visual Technique. Catena 2017, 155, 20-29. [CrossRef]

24. Lehmann, A.; Stahr, K. Nature and Significance of Anthropogenic Urban Soils. J Soils Sediments 2007, 7, 247-260. [CrossRef]

25. Seto, K.C.; Parnell, S.; Elmqvist, T. A Global Outlook on Urbanization. In Urbanization, Biodiversity and Ecosystem Services: Challenges and Opportunities; Elqvist, T., Fragkias, M., Goodness, J., MGüneralp, B., Marcotullio, P.J., McDonald, R.I., Parnell, S., Schewenius, M., Sendstad, M., Seto, K.C., et al., Eds.; Springer: Dordrecht, The Netherlands; Heidelberg, Germany; New York, NY, USA; London, UK, 2013; p. pp. 755. 
26. Morel, J.L.; Burghardt, W.; Kim, K.H.; Tahoun, S.A.; Zhang, G.L.; Shaw, R.K.; Boularbah, A.; Charzyński, P.; Siebe, C.; Riddle, R.L.; et al. Soils within Cities_Global Approaches to Their Sustainable Management; Levin, M.J., Kim, K.-H.J., Morel, J.L., Burghardt, W., Charzynski, P., Shaw, R.K., IUSS Working Group SUITMA, Eds.; Schweizerbart Science Publishers: Stuttgart, Germany, 2017.

27. Deeb, M.; Groffman, P.M.; Joyner, J.L.; Lozefski, G.; Paltseva, A.; Lin, B.; Mania, K.; Cao, D.L.; McLaughlin, J.; Muth, T.; et al. Soil and Microbial Properties of Green Infrastructure Stormwater Management Systems. Ecol. Eng. 2018, 125, 68-75. [CrossRef]

28. European Commission. Communication from the Commission to The European Parliament, The Council, The European Economic And Social Committee and The Committee of The Regions Green Infrastructure (Gi)_Enhancing Europe's Natural Capital. 2013. Available online: https:/ / eur-lex.europa.eu/legal-content/EN/TXT/?uri=CELEX:52013DC0249 (accessed on 15 March 2021).

29. Charzynski, P.; Galbraith, J.M.; Kabala, C.; Kühn, D.; Prokofeva, T.V.; Vasenev, V.I. Classification of Urban Soils. In Soils within Cities; Levine, M.J., Kim, K.-H.J., Morel, J.-L., Burghardt, W., Charzynski, P., Shaw, R.K., Eds.; Schweizerbart Science Publishers: Stuttgart, Germany, 2017; pp. 93-106.

30. Heymans, A.; Breadsell, J.; Morrison, G.M.; Byrne, J.J.; Eon, C. Ecological Urban Planning and Design: A Systematic Literature Review. Sustainability 2019, 11, 3723. [CrossRef]

31. Moher, D.; Liberati, A.; Tetzlaff, J.; Altman, D.G. Preferred Reporting Items for Systematic Reviews and Meta-Analyses: The PRISMA Statement. J. Clin. Epidemiol. 2010, 62, 1006-1012. [CrossRef] [PubMed]

32. Bustami, R.A.; Belusko, M.; Ward, J.; Beecham, S. Vertical Greenery Systems: A Systematic Review of Research Trends. Build. Environ. 2018, 146, 226-237. [CrossRef]

33. Mavrigiannaki, A.; Ampatzi, E. Latent Heat Storage in Building Elements: A Systematic Review on Properties and Contextual Performance Factors. Renew. Sustain. Energy Rev. 2016, 60, 852-866. [CrossRef]

34. Mosannenzadeh, F; Vettorato, D. Defining Smart City. A Conceptual Framework Based on Keyword Analysis. TeMA J. Land Use Mobil. Environ. 2014, 683-694. [CrossRef]

35. Haines-Young, R.; Potschin, M. Common International Classification OfEcosystem Services (CICES) V5.1 and Guidance on the Application of the Revised Structure; Fabis Consulting: Nottingham, UK, 2018.

36. Wang, H.; Mei, C.; Liu, J.H.; Shao, W.W. A New Strategy for Integrated Urban Water Management in China: Sponge City. Sci. China Technol. Sci. 2018, 61, 317-329. [CrossRef]

37. Rodríguez-Rojas, M.I.; Huertas-Fernández, F.; Moreno, B.; Martínez, G.; Grindlay, A.L. A Study of the Application of Permeable Pavements as a Sustainable Technique for the Mitigation of Soil Sealing in Cities: A Case Study in the South of Spain. J. Environ. Manage. 2018, 205, 151-162. [CrossRef] [PubMed]

38. Vineyard, D.; Ingwersen, W.W.; Hawkins, T.R.; Xue, X.; Demeke, B.; Shuster, W. Comparing Green and Grey Infrastructure Using Life Cycle Cost and Environmental Impact: A Rain Garden Case Study in Cincinnati, OH. J. Am. Water Resour. Assoc. 2015, 51, 1342-1360. [CrossRef]

39. Ristić, R.; Radić, B.; Miljanović, V.; Trivan, G.; Ljujić, M.; Letić, L.; Savić, R. Blue-Green Corridors as a Tool for Mitigation of Natural Hazards and Restoration of Urbanized Areas: A Case Study of Belgrade City. Spatium 2013, 30, 18-22. [CrossRef]

40. Maragno, D.; Gaglio, M.; Robbi, M.; Appiotti, F.; Fano, E.A.; Gissi, E. Fine-Scale Analysis of Urban Flooding Reduction from Green Infrastructure: An Ecosystem Services Approach for the Management of Water Flows. Ecol. Modell. 2018, 386, 1-10. [CrossRef]

41. Martínez-Graña, A.M.; Rodríguez, V.V. Remote Sensing and GIS Applied to the Landscape for the Environmental Restoration of Urbanizations by Means of 3D Virtual Reconstruction and Visualization (Salamanca, Spain). ISPRS Int. J. Geo-Inf. 2016, 5, 2. [CrossRef]

42. Bardos, R.P.; Jones, S.; Stephenson, I.; Menger, P.; Beumer, V.; Neonato, F.; Maring, L.; Ferber, U.; Track, T.; Wendler, K. Optimising Value from the Soft Re-Use of Brownfield Sites. Sci. Total Environ. 2016, 563-564, 769-782. [CrossRef]

43. De Sousa, C. The Greening of Urban Post-Industrial Landscapes: Past Practices and Emerging Trends. Local Environ. 2014, 19, 1049-1067. [CrossRef]

44. Shetty, N.; Hu, R.; Hoch, J.; Mailloux, B.; Palmer, M.; Menge, D.N.L.; McGuire, K.; McGillis, W.; Culligan, P. Quantifying Urban Bioswale Nitrogen Cycling in the Soil, Gas, and Plant Phases. Water 2018, 10, 1627. [CrossRef]

45. Wang, J.; Banzhaf, E. Towards a Better Understanding of Green Infrastructure: A Critical Review. Ecol. Indic. 2018, 85, 758-772. [CrossRef]

46. Pauleit, S.; Liu, L.; Ahern, J.; Kazmierczak, A. Planning to Promote Ecological Services in the City. In Urban Ecology: Patterns, Processes, and Applications; Niemela, J., Breuste, J.H., Guntenspergen, G., McIntyre, N.E., Elmqvist, T., James, P., Eds.; Oxford University Press: Oxford, UK, 2011; pp. 272-285.

47. Ajmone-Marsan, F.; Certini, G.; Scalenghe, R. Describing Urban Soils through a Faceted System Ensures More Informed Decision-Making. Land Use Policy 2016, 51, 109-119. [CrossRef]

48. Xing, Y.; Jones, P.; Donnison, I. Characterisation of Nature-Based Solutions for the Built Environment. Sustainability 2017, 9 , 149. [CrossRef]

49. Voghera, A.; Giudice, B. Evaluating and Planning Green Infrastructure: A Strategic Perspective for Sustainability and Resilience. Sustainability 2019, 11, 2726. [CrossRef]

50. Ayers, E.M.; Kangas, P. Soil Layer Development and Biota in Bioretention. Water 2018, 10, 1587. [CrossRef]

51. Dierkes, C. Entsiegelung Mit Wasserdurchlässigen Flächenbelägen-Zurück Zum Natürlichen Wasserkreislauf. In IKT-Forum Niederschlagswasser, Vegetation \& Infrastruktur; IKT Institut für unterirdische Infrastruktur: Frankfurt, Germany, 2015. 
52. U.S. Environmental Protection Agency. Green Infrastructure Strategic Agenda 2013; 2013. Available online: https: / / www.epa.gov / sites/production/files/2015-10/documents/2013_gi_final_agenda_101713_0.pdf (accessed on 15 March 2021).

53. Brudler, S.; Arnbjerg-Nielsen, K.; Hauschild, M.Z.; Ammitsøe, C.; Hénonin, J.; Rygaard, M. Life Cycle Assessment of Point Source Emissions and Infrastructure Impacts of Four Types of Urban Stormwater Systems. Water Res. 2019, 383-394. [CrossRef] [PubMed]

54. Anderson, B.S.; Phillips, B.M.; Voorhees, J.P.; Siegler, K.; Tjeerdema, R. Bioswales Reduce Contaminants Associated with Toxicity in Urban Storm Water. Environ. Toxicol. Chem. 2016, 35, 3124-3134. [CrossRef] [PubMed]

55. Flynn, K.M.; Traver, R.G. Green Infrastructure Life Cycle Assessment: A Bio-Infiltration Case Study. Ecol. Eng. 2013, 55, 9-22. [CrossRef]

56. Shafique, M.; Kim, R. Green Stormwater Infrastructure with Low Impact Development Concept: A Review of Current Research. Desalin. Water Treat. 2017, 83, 16-29. [CrossRef]

57. Nguyen, T.T.; Ngo, H.H.; Guo, W.; Wang, X.C.; Ren, N.; Li, G.; Ding, J.; Liang, H. Implementation of a Specific Urban Water Management-Sponge City. Sci. Total Environ. 2019, 652, 147-162. [CrossRef]

58. Ishimatsu, K.; Ito, K.; Mitani, Y.; Tanaka, Y.; Sugahara, T.; Naka, Y. Use of Rain Gardens for Stormwater Management in Urban Design and Planning. Landsc. Ecol. Eng. 2017, 13, 205-212. [CrossRef]

59. Berland, A.; Shiflett, S.A.; Shuster, W.D.; Garmestani, A.S.; Goddard, H.C.; Herrmann, D.L.; Hopton, M.E. The Role of Trees in Urban Stormwater Management. Landsc. Urban Plan. 2017, 162, 167-177. [CrossRef] [PubMed]

60. Caplan, J.S.; Galanti, R.C.; Olshevski, S.; Eisenman, S.W. Water Relations of Street Trees in Green Infrastructure Tree Trench Systems. Urban For. Urban Green. 2019, 41, 170-178. [CrossRef]

61. Kazak, J.K.; Chruściński, J.; Szewrański, S. The Development of a Novel Decision Support System for the Location of Green Infrastructure for Stormwater Management. Sustainability 2018, 10, 4388. [CrossRef]

62. Beery, T. Engaging the Private Homeowner: Linking Climate Change and Green Stormwater Infrastructure. Sustainability 2018, 10, 4791. [CrossRef]

63. Sansalone, J.; Raje, S.; Kertesz, R.; Maccarone, K.; Seltzer, K.; Siminari, M.; Simms, P.; Wood, B. Retrofitting Impervious Urban Infrastructure with Green Technology for Rainfall-Runoff Restoration, Indirect Reuse and Pollution Load Reduction. Environ. Pollut. 2013, 183, 204-212. [CrossRef]

64. Gavrić, S.; Larm, T.; Österlund, H.; Marsalek, J.; Wahlsten, A.; Viklander, M. Measurement and Conceptual Modelling of Retention of Metals $(\mathrm{Cu}, \mathrm{Pb}, \mathrm{Zn})$ in Soils of Three Grass Swales. J. Hydrol. 2019, 574, 1053-1061. [CrossRef]

65. Morash, J.; Wright, A.; LeBleu, C.; Meder, A.; Kessler, R.; Brantley, E.; Howe, J. Increasing Sustainability of Residential Areas Using Rain Gardens to Improve Pollutant Capture, Biodiversity and Ecosystem Resilience. Sustainability 2019, 11, 3269. [CrossRef]

66. Ordóñez-Barona, C.; Sabetski, V.; Millward, A.A.; Steenberg, J. De-Icing Salt Contamination Reduces Urban Tree Performance in Structural Soil Cells. Environ. Pollut. 2018, 234, 562-571. [CrossRef]

67. Faucette, B.; Cardoso, F.; Mulbry, W.; Millner, P. Performance of Compost Filtration Practice for Green Infrastructure Stormwater Applications. Water Environ. Res. 2013, 85, 806-814. [CrossRef] [PubMed]

68. Dagenais, D.; Brisson, J.; Fletcher, T.D. The Role of Plants in Bioretention Systems; Does the Science Underpin Current Guidance? Ecol. Eng. 2018, 120, 532-545. [CrossRef]

69. Nidzgorski, D.A.; Hobbie, S.E. Urban Trees Reduce Nutrient Leaching to Groundwater. Ecol. Appl. 2016, 26, 1566-1580. [CrossRef]

70. Norton, B.A.; Bending, G.D.; Clark, R.; Corstanje, R.; Dunnett, N.; Evans, K.L.; Grafius, D.R.; Gravestock, E.; Grice, S.M.; Harris, J.A.; et al. Urban Meadows as an Alternative to Short Mown Grassland: Effects of Composition and Height on Biodiversity. Ecol. Appl. 2019, 29, 1095-1115. [CrossRef] [PubMed]

71. Gill, A.S.; Lee, A.; McGuire, K.L. Phylogenetic and Functional Diversity of Total (DNA) and Expressed (RNA) Bacterial Communities in Urban Green Infrastructure Bioswale Soils. Appl. Environ. Microbiol. 2017, 83, 115. [CrossRef] [PubMed]

72. Kövendi-Jakó, A.; Halassy, M.; Csecserits, A.; Hülber, K.; Szitár, K.; Wrbka, T.; Török, K. Three Years of Vegetation Development Worth 30 Years of Secondary Succession in Urban-Industrial Grassland Restoration. Appl. Veg. Sci. 2019, 22, 138-149. [CrossRef]

73. Lal, R.; Zechmeister-Boltenstern, S.; Dáz-Pinés, E.; Spann, C.; Hofmann, K.; Schnecker, J.; Reinsch, S.; Jungkunst, H.F.; Horvath, T.; Erasmi, S.; et al. Soil and Climate, 1st ed.; Lal, R., Stewart, B.A., Eds.; CRC Press: Boca-Raton, FL, USA, 2018.

74. Amelung, W.; Bossio, D.; de Vries, W.; Kögel-Knabner, I.; Lehmann, J.; Amundson, R.; Bol, R.; Collins, C.; Lal, R.; Leifeld, J.; et al. Towards a Global-Scale Soil Climate Mitigation Strategy. Nat. Commun. 2020, 11, 1-10. [CrossRef]

75. Kavehei, E.; Jenkins, G.A.; Adame, M.F.; Lemckert, C. Carbon Sequestration Potential for Mitigating the Carbon Footprint of Green Stormwater Infrastructure. Renew. Sustain. Energy Rev. 2018, 94, 1179-1191. [CrossRef]

76. Wang, Z.H.; Zhao, X.; Yang, J.; Song, J. Cooling and Energy Saving Potentials of Shade Trees and Urban Lawns in a Desert City. Appl. Energy 2016, 161, 437-444. [CrossRef]

77. Fung, C.K.W.; Jim, C.Y. Microclimatic Resilience of Subtropical Woodlands and Urban-Forest Benefits. Urban For. Urban Green. 2019, 42, 100-112. [CrossRef]

78. Bartesaghi Koc, C.; Osmond, P.; Peters, A. Evaluating the Cooling Effects of Green Infrastructure: A Systematic Review of Methods, Indicators and Data Sources. Sol. Energy 2018, 166, 486-508. [CrossRef]

79. Makido, Y.; Hellman, D.; Shandas, V. Nature-Based Designs to Mitigate Urban Heat: The Efficacy of Green Infrastructure Treatments in Portland, Oregon. Atmosphere 2019, 10, 282. [CrossRef] 
80. Gunawardena, K.R.; Wells, M.J.; Kershaw, T. Utilising Green and Bluespace to Mitigate Urban Heat Island Intensity. Sci. Total Environ. 2017, 584-585, 1040-1055. [CrossRef] [PubMed]

81. Arnold, J.; Kleemann, J.; Fürst, C. A Differentiated Spatial Assessment of Urban Ecosystem Services Based on Land Use Data in Halle, Germany. Land 2018, 7, 101. [CrossRef]

82. Roy, S.; Byrne, J.; Pickering, C. A Systematic Quantitative Review of Urban Tree Benefits, Costs, and Assessment Methods across Cities in Different Climatic Zones. Urban For. Urban Green. 2012, 11, 351-363. [CrossRef]

83. Barron, S.; Sheppard, S.R.J.; Condon, P.M. Urban Forest Indicators for Planning and Designing Future Forests. Forests 2016, 7, 208. [CrossRef]

84. Zölch, T.; Rahman, M.A.; Pfleiderer, E.; Wagner, G.; Pauleit, S. Designing Public Squares with Green Infrastructure to Optimize Human Thermal Comfort. Build. Environ. 2019, 149, 640-654. [CrossRef]

85. Herrán Fernández, Á.; Lacalle, R.G.; del Burgo, M.J.; Martínez Azkuenaga, M.; Vilela Lozano, J. First Results of Technosols Constructed from Municipal Waste in Vitoria-Gasteiz (Spain). Spanish J. Soil Sci. 2016, 6, 64-81. (In Spanish) [CrossRef]

86. Salvati, L.; Quatrini, V.; Barbati, A.; Tomao, A.; Mavrakis, A.; Serra, P.; Sabbi, A.; Merlini, P.; Corona, P. Soil Occupation Efficiency and Landscape Conservation in Four Mediterranean Urban Regions. Urban For. Urban Green. 2016, 20, 419-427. [CrossRef]

87. Li, G.; Sun, G.X.; Ren, Y.; Luo, X.S.; Zhu, Y.G. Urban Soil and Human Health: A Review. Eur. J. Soil Sci. 2018, 69, 196-215. [CrossRef]

88. Rodas, J.M.C.; Gómez, J.M.N.; Castanho, R.A.; Cabezas, J. Land Valuation Sustainable Model of Urban Planning Development: A Case Study in Badajoz, Spain. Sustainability 2018, 10, 1450. [CrossRef] 